\title{
HOW DOES A SMART CITY STRUCTURE ITS LABOR MARKET POLICY? A COMPARATIVE STUDY OF GLOBAL CITIES
}

\author{
Ney Nakazato Miyahira, Wilson Aparecido Costa de Amorim \\ and Daielly Melina Nassif Mantovani \\ Faculdade de Economia, Administração, e Contabilidade da Universidade de São Paulo - FEA/USP, Brazil
}

\begin{abstract}
Smart City is defined as a system of people interacting and using energies, materials, services and financing to catalyze economic development and improve the quality of life. Faced with such multidisciplinarity brought by the concept, there is concern about the efficiency of public management and, more specifically, the focus of this research: how public policies can influence the dynamics of the labor market, impacting on the creation and maintenance of a smart city.

With the focus on labor market policies, this work is at the intersection of two research fields: smart city and public management. From the first field, we mean the evolution of the studies in smart city, the evaluative dimensions commonly used for a smart city, and it is understood that a city will only be smart if it uses technology with the main purpose of providing better living conditions for citizens, in this case, providing adequate working conditions. From the second field of study, the models experienced in public management are evolved, focusing on public policies on the labor market, so that it is possible to identify a smart city evaluative dimension in labor market policy: active policies and passive employment policies. The theoretical lens used in the research will be the institutional approach, since it allows analyzing how much the current configurations of given context, with its institutions guiding the human interactions, predispose formations more or less adherent to a model of smart city propitiating e-democracy or e-government. The contextual formatting to be analyzed will be different types of market economies found in each city under future analysis.

This research is being developed to support a doctoral thesis that intend to realize comparative case studies of global cities (São Paulo and Shanghai). This article will present the bibliographic review, that is, the survey of the conceptual contribution that will guide future researches.
\end{abstract}

\section{KEYWORDS}

Labor Market, Public Policies, Smart City

\section{INTRODUCTION}

Currently, more than half of the global population already resides in cities. According to UN estimates, this number will reach 70\% in 2050 (Panhan et al, 2016). If, on the one hand, the fourth industrial revolution (driven by artificial intelligence) brings consistent changes in the day-to-day functioning of cities, intervening in their flow, dynamics, economy and culture itself by reformatting the values of society, for on the other hand, all this technology has not yet proved capable of meeting traditional issues of municipal management: transport, infrastructure, housing, employment, among others. (Panhan, et al, 2016).

The concept of smart cities arises from the conscious effort to use information and communication technologies to significantly change the lives and work of people in urban territories, improving the lives of the citizens who live in them (Porter \& Heppelmann, 2014). This research focuses on the labor market and understands that a city will be smart when it has management with integrative and sustainable solutions, having the current public policies as a synergistic driver of such management. The general research question is how does a smart city structure its labor market policy?

The general objective is to characterize and analyze the way a smart city structures its labor market policy based on studies of two cities linked to two different national realities, according to their institutional characteristics. To achieve this objective, the research will discuss the following specific objectives: a) Identify and analyze the cities of São Paulo and Shanghai from the perspective of managing their labor markets; 
b) Compare and analyze the two realities of market economies: hierarchical and coordinated socialism (São Paulo and Shanghai, respectively) and analyze how the typology of market economies can influence the structuring of work relationship systems in stimulating or inhibiting to get a smart city; and c) Critically compare how São Paulo and Shanghai position themselves in the evaluative dimension of public policies aimed at the labor market, cataloging the actions in active and passive labor market policies.

In order to achieve these objectives, it is necessary to recover theoretical references and analysis lenses that allow the multidisciplinary theme proposal to be analyzed. This work comprises the proposed bibliographic review for conducting this research in progress, for a doctoral thesis.

\section{THEORETICAL BASIS}

To fulfill with the precise delimitation of the research, it will be necessary to go through three major themes: a) Smart city: the possible forms of conceptualization and its consequent approaches, the evolution of studies and their evaluative dimensions, cities as spaces for flow and social networks ; b) Institutional approach: the theoretical lens chosen to study the phenomenon and the characterization of institutional factors in a smart city; and c) public management: rescuing the management model of public administration and addressing the formulation of policies in the labor market, from the focus of labor relations systems. From the confluence of these themes, the possibility will emerge of showing an evaluative dimension of a smart city in public labor market policies.

\subsection{The Concept of Smart City and its Multiple Dimensions}

The concept of smart cities, although relatively recent, has already undergone transformations and adaptations. Initially it was defined as an urban space with intensive use of context-sensitive communication and information technologies, urban management and social action driven by data (Albino et al, 2015). In the search for its implementation, the theme was multidisciplinary, expanding the concept to a system of people interacting and using energy, materials, services and financing to catalyze economic development and improve the quality of life. In this expansion of the concept, there is a focus on applied social sciences (Dameri, 2013), which is concerned with the efficiency of public management, with repercussions on facilitating the urban space to be configured as smart, in terms of the efficient provision of public services ( Washburn et al, 2009), development (Giffinger et al, 2007) and social well-being (Cocchia, 2014).

A point that deserves to be highlighted is that the concept of smart city, although it brings a geographical delimitation for the understanding of actions and investments in urban space, is not restricted to the physical and geographic contours of a city. It is understood that a city, through the actions of its community, can have repercussions in regions, network of cities or nations. (Dameri, 2013).

For the purposes of this research, the operational definition of smart city will be: a geographically delimited urban space, managed by a local government, whose management responsibilities include: monitoring and integrating resources, people, environment, economic production, provision of services and financing in order to catalyze economic development, improve the quality of life and fully exercise citizenship. (Dameri, 2013; Washburn et al, 2009; Giffinger et al, 2007; Cocchia, 2014).

Studies show that the classification of a city in smart city can take into account different indicators or dimensions of analysis (Albino et al, 2015; Dameri, 2013). Among the existing classifications in the literature and which are of recurrent use, all bear the resemblance that the performance of a city must be evaluated in a multidimensional and holistic perspective, integrating the tangible and intangible resources existing in the environment (Rodrigues \& Franco, 2018). Thus, even if the focus is on labor market policies, it is necessary to know that it alone will not raise a city to smart status, but it, in connectivity with other policies, will heat up the economy, improve the quality of life and increase the human development Index.

\subsection{The Theoretical Analysis Lens: The Institutional Approach}

North (1990) defined institutions as "the constraints created by man to shape human interactions". Institutionalization is seen as a social process in which individuals accept social reality, regardless of their own views and organizations, created and managed by individuals, are under pressure to acquire and maintain 
legitimacy in relation to the environment (Wright, 1992). The institutionalization theory is based on the idea that the various structures, programs and practices are legitimized by the social construction of reality and must correspond to it (Kishtainy et al., 2013). Thus, institutional factors consist of norms adopted by the institution or even institutional attributes of its insertion context that interfere in management practices, modifying its characteristics, shaping its meanings and its final objectives (Dimaggio \& Powell, 2007).

The institutional approach contributes to the study of smart city by pointing out that not all decisions are rational and that the practices adopted, in many cases, may be the result of a social construction (Wright, 1992). The author reinforces the idea that there is no rationality in all decisions and that social constructions lead to different choices and configurations, but without necessarily comparing themselves as better or worse, but rather, the most appropriate to a given reality. This view makes it possible to understand that there will not be a single political-economic-social scenario for the configuration of a smart city, but it will be possible different configurations that, understanding and respecting their differences, traces different paths to reach a smart city status. One way of identifying different contexts is through the prism of the varieties of market economies. The cities surveyed, São Paulo and Shanghai, can be classified, respectively, as hierarchical market capitalism and coordinated market socialism.

Hierarchical market economies, present in Latin American countries, have the following characteristics: Organizations coordinate their activities through a strong hierarchy, which prevents the full adoption of the liberal or coordinated model; Direct hierarchical control over companies, separately and market concentration; Institutions' deficiency in mediating labor relations and promoting greater investments in training and competence development; Unions are more politicized, controlled by the State and represent a small portion of workers, due to the existence of a large informal market and low membership; High turnover, few employees with long-term relationships in organizations; and Low levels of education, despite recent advances and low public and private investment in training. (Hall and Soskice, 2003; Schneider, 2007).

Coordinated market economies are present in countries such as Germany, Japan, Switzerland, the Netherlands, Belgium, Sweden, Norway, Denmark, Finland and Austria and are characterized by: Organizations coordinate their activities through a set of organizations and institutions, arranged in non-market relations; Market balance is achieved by strategic interactions between organizations and other actors; Non-market coordination modes outline incomplete relationships and contracts; The actors receive greater institutional support for their strategic interactions - specific or collaborative industrial training; Economic adjustments take longer (it takes time to get in and out of a crisis) and unemployment rates are lower; and Education and training system that allow specific investments of human capital in companies and sometimes defined industries. (Hall and Soskice, 2003; Schneider, 2007).

Based on the two different contexts, it will be possible to analyze the institutional factors affecting each city and assess how much each configuration facilitates the configuration of a smart city.

\subsection{Public Management: Policies Leading to e-Government or to e-Democracy}

Public management can be understood as the function of managing resources, applying laws and formulating and implementing public policies in favor of order, justice and the common good, in short, defending public interests. Although it is not exclusive to the government, it ends up being its main active entity, given its function of directing and administering the State (Dias \& Matos, 2012). The focus of the research is on city management, but it is necessary to understand such cohesive management with guidelines and policies of regional and national governments.

Levy (2016) lists some challenges for Public Management when studying structural conflicts in the processes of implementing managerial reforms in the countries of the Organization for Economic Cooperation and Development (OECD): institutional inertia, expansion of bureaucratic controls, administrative efficiency, assertiveness in role of public agencies and agility in the timing of adjustments.

In order to achieve many of these challenges, research indicates that a possible way would be the empowerment of city administrations, the endogenous regional development approach (Krom \& Manolescu, 2007). Dias and Matos (2012) affirm that because the municipalities are the political entities closest to the population, they are the triggers for the economic development of the region, when they dedicate themselves to the local economic development and, therefore, the public policies of a city would be in the center of a region's development. 
Public policies can be understood as the set of principles, criteria and lines of action that guarantee and allow the management of the State to solve national problems (Dias \& Matos, 2012). For this research, there is the identification that the arrangement of public policies can lead to two models of smart city. The first, understood as the application of technology, making public services efficient and effective, enabling the manipulation, control and efficient integration of data, optimizing the allocation of resources, producing performance indicators of public services that feedback the improvement of services. Called e-government, it makes intensive use of technology in public management. Indicators of speed and quality of public services are highlighted in this model.

The second model characterizes e-democracy and also uses technology to make the provision of public services more efficient, but with the main motto of providing better living conditions, a higher degree of satisfaction of the inhabitants and greater involvement of civil society in the administration. In this model, technology is seen as a means or a resource to achieve the purpose of greater exercise of citizenship.

If for the first model, the labor market will import as it boosts the economy and, consequently, local growth; in the second model it is also considered in its influence on discrimination, prejudice, job deprivation, social risks of precariousness at work, among other aspects that assess human rights. The second model is concerned with technological use and imposes limits so that there is no social control that hurts privacy.

\subsection{Labor Market Policies}

Guimarães (2009) points out that the labor market must be understood in all its heterogeneous and multifaceted aspect. Such a view becomes even more relevant when one observes the changes arising from the restructuring of productive activities, the flexibilization of relations and the conditions of use of work, reflecting the socio-technological transformations, which expand work activity beyond the limits of formal work. Thus, state intervention in the labor market needs to consider these new conditions of work and thus correct market failures, combat unemployment, improve the insertion of labor in the market and stimulate increased productivity and income.

Such intervention can be done primarily in two ways: through active policies and through passive policies. The first aims to increase the level and employment and wages of people who have difficulty entering the labor market. The second, on the other hand, refers to ensuring a certain level of consumption and well-being for those workers who were unable to enter the economic activity (Borjas, 2012).

Active policies, according to Borjas (2012) comprise the actions: job creation, training measures, public labor intermediation system and development of small and micro companies and activities on their own and generates so much income effect that it reduces hours the effect of substitution, which increases the hours worked. It is necessary to analyze which effect dominates.

Passive policies are those aimed at increasing non-work income or transferring income to the unemployed (unemployment insurance), or at reducing the economically active population (early retirement or extension of the school cycle); its effects are the reduction of individuals' working hours or the possibility of the individual entering the workforce (Borjas 2012).

The research will adopt the actions of active and passive policies as the evaluative dimensions of a labor market policy, thus proposing a specific instrument to assess whether a city is smart in the aspect of labor market policies.

\section{CONCLUSION}

The theoretical framework gathered in this work makes it possible to bring together two fields of research: Smart City and the Labor Market, which, under the lens of Institutional Theory, reveals conditions of active and passive policy actions that predispose to more or less harmonious adjustments in the city labor market.

At the conclusion of this research, of a qualitative nature, it is expected that it will explain the contribution of labor market policy management to the achievement and maintenance of a smart city. For theorists, it will be an opportunity to deepen their studies on the evaluative dimension of a smart city in public policies aimed at the labor market. For practitioners, it will point out possibilities for formatting labor market policies, according to institutional conditions and current market economies. 


\section{REFERENCES}

Albino, V. et al, 2015. Smart Cities: Definitions, Dimensions, Performance, and Initiatives. Journal of Urban Technology, Vol. 22, No. 1, pp 3-21.

Borjas, G., 2012. Labor Economics. 5 ed. McGraw-Hill Companies, New York.

Cocchia, A., 2014. Smart and digital city: A systematic literature review in Smart City; Springer, Berlin, pp. $13-43$.

Dameri, R. P., 2013. Searching for smart city definition: a comprehensive proposal. International Journal of Computers \& Technology, 11(5), pp 2544-2551.

Dias, R.; \& Matos, F., 2012. Políticas públicas - princípios, propósitos e processos. Editora Atlas, São Paulo.

Dimaggio, P.J.; Powell W.W., 2007. Jaula de ferro revisitada: isomorfismo institucional e racionalidade coletiva nos campos organizacionais. In Caldas, M.P.; Bertero, C.O..(coords.) Teoria das organizações. Editora Atlas, São Paulo.

Giffinger, R., et al, 2007. Smart cities. Ranking of European medium-sized cities; Site: http://www.smartcities.eu/download/smart_cities_final_report.pdf

Guimaraes, N. A., 2009. À procura de Trabalho - Instituições de Mercado e Redes. Argvmentvm, Belo Horizonte.

Hall, P.; \& Soskice, D. 2003. Varieties of capitalism - The institutional foundations of comparative advantage. Oxford Press, Oxford.

Kishtainy, N. et al, 2013. O Livro da Economia. [tradução Carlos S. Mendes Rosa]. Globo, São Paulo.

Krom, V; \& Manolescu, F. M. K., 2007. Evolução do Pensamento Econômico Regional: Algumas considerações. In: Chamon, E. M. Q. O. Gestão de Organizações Públicas e Privadas. Brasport, Rio de Janeiro.

Levy, E., 2016. Desafios Contemporâneos à Gestão Pública. In: Tópicos Essenciais sobre Gestão Pública. Organizadores: Bassoti, I. M.; Santos, T. S. EGAP, São Paulo.

North, D. C., 1990. Behavioral assumptions in a theory of institutions. In Institutions, institutional change and economic performance. University Press, Cambridge.

Panhan, A. M. et al, 2016. Construindo Cidades Inteligentes. Appris, Curitiba.

Porter, M. E. \& Heppelmann, J. E., 2014. How Smart, Connected Products Are Transforming Competition. Harvard Business Review. Nov, pp.96-112, 114.

Rodrigues, M.; \& Franco, M., 2018. Measuring the Performance in Creative Cities: Proposal of a Multidimensional Model. Sustainability - MDPI, Open Access Journal, vol. 10(11), pp 1-21.

Schneider, B.R., 2007. Hierarchical market economies and varieties of capitalism in Latin America. Journal of Latin American Studies, 41, 2009. pp 553-571.

Washburn, D., 2009. Helping CIOs understand "smart city" initiatives. Growth, 17, pp 1-17.

Wright, P. M.; \& McMahan, G. C., 1992. Theoretical Perspectives for Strategic Human Resource Management. Journal of Management. v. 18. n.2, pp 295-320. 